\title{
Quality of life at work: perception of nurses and nursing technicians from a hospital da Serra Gaúcha, RS, Brazil
}

\author{
Qualidade de vida no trabalho: percepção de enfermeiros e técnicos em \\ enfermagem de um hospital da Serra Gaúcha, RS, Brasil
}

\author{
Eliana Rustick Migowski* \\ João Carlos Jaccottet Piccoli ** \\ Daniela Müller de Quevedo***
}

\begin{abstract}
The present study aims to analyze the quality of work life (QLW) through application of the Nursing Questionnaire of quality of life at work (QWLQ-78), in a hospital in Serra Gaúcha (RS-BR). The sampling made was, for convenience, with nursing professionals who were at work at the time of data collection and who have agreed to participate in this study. The questionnaires were applied in November 2014, having been delivered 149 questionnaires, of which 95 were totally filled The instrument was divided into four domains (Physical/Health; Psychological; Professional; and Personal) and the data originated from questions relating to the four domains were analyzed in the statistical package SPSS version 20.0. All domains were classified as satisfactory. A strong correlation was observed between all domains and QLW, notably in the personal domain $(r=0,866)$, followed by Psychological and Professional Domains (both $p=0.819)$. The lowest correlation occurred between the Physical/Health domain and QWL $(r=0.762)$ and between this domain and the rest of others. The study showed a satisfactory perception of QWL among the studied sample. In this way, the development of several actions involving factors inserted in the four areas tend to elevate the QLW in this institution. Among them, it could be mentioned the improvement of hierarchical social and family relationships; encouragement of physical activities and gymnastics; the self-esteem and freedom of expression; the feeling of belonging and fairness; the feedback; and access to information on the various work processes.
\end{abstract}

Keywords: Quality of Life. Hospital. Nursing.

\begin{abstract}
Resumo
A presente investigação descritiva, de corte transversal, avaliou a qualidade de vida percebida no trabalho de enfermeiros e técnicos em enfermagem de um hospital da Serra Gaúcha, Rio Grande do Sul, selecionados por conveniência. Os questionários foram aplicados no mês de novembro de 2014, tendo sido entregues 149 questionários, dos quais 95 estavam totalmente preenchidos. Foi utilizado o questionário de avaliação da qualidade de vida no trabalho - QWLQ78, dividido em quatro domínios (Físico/Saúde; Psicológico; Profissional e Pessoal) e os dados submetidos à estatística descritiva (médias e desvios-padrão) e cálculo de frequências absolutas e relativas. Os resultados obtidos em todos os domínios apontaram para uma percepção satisfatória de qualidade de vida no trabalho (QVT). Foi observada uma forte correlação positiva entre todos os domínios e a QVT, notadamente no Domínio Pessoal (r=0,866), seguido pelos Domínios Psicológico e Profissional (ambos com r=0,819). A menor correlação ocorrida foi entre o domínio Físico/ Saúde e QVT (r=0,762) e entre esse domínio e os demais. O estudo apresentou uma percepção satisfatória de QVT na amostra investigada. Dessa forma, o desenvolvimento de ações diversas envolvendo os fatores que estão inseridos nos quatro domínios tendem a elevar a QVT geral na instituição. Dentre elas, podem ser citadas a melhoria das relações hierárquicas, sociais e familiares; o incentivo de atividades físicas e ginástica laboral; a autoestima e a liberdade de expressão; o sentimento de pertencimento e equidade; o feedback; e o acesso às informações sobre os diversos processos de trabalho.
\end{abstract}

Palavras-chave: Qualidade de vida. Hospital. Enfermagem.

DOI: 10.15343/0104-7809.20164002189198

\footnotetext{
\# Artigo desenvolvido a partir da dissertação de Mestrado (Qualidade de Vida no Trabalho: a Percepção de Enfermeiros e Técnicos em Enfermagem de um Hospital da Serra Gaúcha, RS), apresentado ao Programa de Pós-Graduação em Diversidade Cultural e Inclusão Social da Universidade FEEVALE, Novo Hamburgo, 2015.

*Escola Superior de Teologia ( EST) - Escola Técnica de Enfermagem (ETE), Novo Hamburgo - RS, Brasil. E-mail: elianamig@yahoo. com.br

${ }^{* *}$ Universidade Feevale - Novo Hamburgo - RS

*** Universidade Federal do Rio Grande do Sul - UFRGS, Novo Hamburgo - RS, Brasil.

Os autores declaram não haver conflitos de interesse.
} 


\section{INTRODUCTION}

The process of globalization and the transformations in the capitalist production way have interfered with the economy, the life conditions of the population, and the work relationships, reflecting on the worker's quality on the professional profile required by the labor market and demand professionals that are in line with the organizational objectives, goals, and results. ${ }^{1,2}$ This context leads the organizations to worry more about the quality of life at work $(\mathrm{QLW})$, since these transformations affect the own environment where it occurs. ${ }^{3}$

Therefore, QLW is related to mobilization, personal compromise, and participation in the well-being of the employee when a task is performed in the company, aiming at achieving the Total Quality goals. An organizational environment, where there is dynamic and contingency management of physical, sociological, and technological factors of the organization of the work, becomes a healthy environment that is prone to an increase in productivity.

Thus, hospital organizations must be considered as a part of this process. A hospital is a complex organization that presents specificities like tacit knowledge, technologies, and diverse infrastructure, besides playing a key role in providing health services. ${ }^{4}$ Its configuration and technical organization can be characterized by the division of work, as well as by different management models. That is the context where the health workers develop their activities.

Such as the nursing workers that represent the biggest contingent among the categories inserted in health institutions and that normally represent $60 \%$ of all the workers in a hospital. ${ }^{5,6}$ As characteristics of this professional category, the long daily shifts thought to cause stress, sleep deficit, vigilance problems, and mood changes must be mentioned. Frequently they are predisposed to risk the quality of the assistance, to have their social withdrawal reflecting on the family or other social segments, besides the imbalance in social life regarding their work schedules. ${ }^{7-10}$

It is believed that analyzing the QLW and the articulations between the elements, directly or

indirectly, interfere with the nurses' perception about their work allows understanding the individual and their reality, while contributing to the development of science, theory and practice of nursing and citizenship, considering nursing as promoting and recovering health and wellness. Regarding the QLW measure, in the Brazilian nursing, there are few instruments specifically built and validated to evaluate the QLW of nurses. ${ }^{11}$

While analysing the impact of these factors on nursing professionals, articles presenting instruments that measure the quality of life were searched between January 2000 and August 2014, in Science Direct, Web of Science, EBSCO, and Spell databases.

However, this search did not bring results. Thus, this study adopts an assessment tool for the quality of life at work, the QWLQ-78 (Quality of Working Life Questionnaire), which has not been used in studies of QLW for nursing, according to the search made in the databases.

Therefore, the following research aimed to investigate the quality of life at work of the sample, according to the physical/health, psychological, personal, and professional domains, while describing the profile of the sample regarding the variables gender and length of service and comparing the perception of quality of life at the general work between the domains.

\section{METHOD}

The sample was selected by convenience and included 95 assistential nurses, managers, and nursing technicians, belonging to a hospital staff in Serra Gaúcha, State of Rio Grande do Sul, with certification that proves its quality through the Hospital Accreditation - Level 3.

All the professionals attending these criteria who were in the working environment when the data were collected and who accepted to participate were included in the study. In November 2014, 149 questionnaires were handed out, from which 95 were totally filled in. A total of 71 hours were used to apply and collect the questionnaires.

At the time the study was carried out, there were 80 open positions for nursing professionals that were compensated by others making 
double shifts, given the difficulties in filling them.

For the data collection, the questionnaire assessing the quality of life at work - QWLQ78 (Quality of Working Life Questionnaire) was used, as it is in the study by Reis Junior, ${ }^{12}$ that aims to assess the quality of life at work. It is divided into four domains: Physical/ Health Domain; Psychology Domain; Personal Domain; and Professional Domain.

The instrument has an assessment scale ranging from 1 to 5 and that is turned into another scale ranging from 0 to 100 . The quality of life at work (QVT) was based on the scale proposed by Sivieiro, 13 where indices lower than 25.5 are considered as unsatisfactory, ranging from 25 to 75 are considered intermediate, and if they are above 75 , satisfactory, Reis Junior ${ }^{12}$ created the following classification: very unsatisfactory (0-22.5); unsatisfactory (22.5-45); neutral (45$55)$; satisfactory (55-77.5); very satisfactory (77.5-100).

The ethical care started when it was approved by the Research Ethics Board (REB) of Universidade Feevale, protocol CAAE 34600114.3.0000.5348 and the signature of a co-participant institution. Subsequently, it was approved by the REB of the institution being researched, protocol CAAE 34600114.3.3001.5305.

The results were tabled and submitted to analysis using descriptive statistics (means and standard deviations) and calculus of absolute and relative frequencies. First, data were submitted to the Kolmogorov-Smirnov normality test $(a=0.05)$. From this, the Spearman - $p$ correlation $(a=0.05)$ was used to check for correlation between the domains of the instrument and the general QLW. To determine the classification of correlation coefficients that were found, the classification by Dancey and Reidy ${ }^{14}$ was used: $p=0.10$ to 0.30 (weak); 0.40 to 0.6 (moderate) and 0.70 to 1 (strong). The data were submitted to the Statistical Package SPSS version 20.0.

\section{RESULTS AND DISCUSSION}

The female predominated in $93.7 \%$ of the sample, with the male prevailing $6.3 \%$. The predominance of female sex was also the result found in other studies. ${ }^{15,16}$ Taking the variable age as a reference, $58 \%$ of the subjects were aged less than or equal to 30 years-old. The mean age of the male subjects was 32 years, and the mean age of the female subjects was 26. Besides, all the domains are classified as satisfactory on the traditional 1-5 scale and later on the scale 0-100 and the classifications regarding the QLW: Physical/Health (M 3,3; SD 0,41; Scale 56.06); Psychological (M 4,80; SD 3,52; Scale 63,12); Personal (M 4,81; SD 3,80; Scale 70.10); Professional (M 4,20; SD 3,30; Scale 57.70); QWL (M 4,42; SD 3,48; Scale $62,24)$.

There is a moderate positive correlation $(p \leq 0.01)$ between the domains of the questionnaire assessing the quality of life at work - QWLQ-78 (Quality of Working Life Questionnaire), and a strong positive correlation $(p \leq 0.01)$ between the general QLW and the domains.

This means that the better the perception of the quality of life is in the Physical/Health, the better the assessment of the other domains is $\left(p=0.498^{* *}, 0.545^{* *}\right.$, and $\left.0.518^{* *}\right)$. The same happens to the Psychological $\left(p=0.498^{* *}\right.$, $0.669^{* *}$, and $\left.0.599^{* *}\right)$, Personal $\left(p=0.545^{* *}\right.$, $0.669^{* *}$, and $\left.0.639^{* *}\right)$, and Professional $\left(p=0.518^{* *}, 0.599^{* *}\right.$ and $\left.0.639^{*}\right)$ domains, respectively. In the domains assessed and the general QLW, a strong positive correlation between the following domains has been observed: Physical $\left(p=0.762^{* *}\right)$, Psychological $\left(p=0.819^{* *}\right)$, Personal $\left(p=0.866^{* *}\right)$, and Professional $\left(p=0.819^{* *}\right)$. Specific questions of the domains are presented below, but as we have a limitation due to the size of the paper, some questions were suppressed, but they can be obtained with the authors.

Table 1 presents the questions of the physical/ health domain where the following aspects are assessed: sleep quality; diet quality; hereditary; sense of comfort; fatigue; satisfaction of the basic physiological needs; chronic diseases; physical activity; workplace exercise; medical care; and stress

It presents that the subjects' health is a factor that changes their QLW, forcing them to use medications regularly as a way to re-establish the conditions of their health due to the demands generated by their work. Such result is supported 
by several studies16-18 that identified aspects related to illness and the use of psychoactive medications in by nursing workers in intensive care units, relating this fact to the stress caused by the daily agitation, among other factors. Therefore, the illness of nursing professionals seems to be a common factor in this study and others mentioned here. This suggests the need to draw more attention for the Physical/Health Domain by the managers.

The practice of workplace exercises was the one with the highest index of dissatisfaction (score 5.50). These results are similar to others ${ }^{19,20}$ that pointed out that, due to the work strain and demands, adding workplace exercises could promote pleasant moments in the work shift, while preventing injuries and diseases and contributing to the quality of life at work.

The proper treatment of these questions can improve the QLW of these professionals, while generating positive repercussions, including less on alienations from their labor activities, or staff rotation, which would demand new specific studies.

On the other hand, it is important to stress some questions of the Table 1 that were classified as satisfactory. Question 61 (score 71.75) addresses the perception of fatigue at the end of a workday, while Question 77 (score 63.00) addresses the perception of comfort in the work environment. The answers given to the first questions were surprising, since it is known that using double shifts as a way to complete the work scale would usually enhance the degree of dissatisfaction. Moreover, a significant portion of the professionals responding the questionnaire has been working for less than a year at that institution (33.70), and this might indicate having less experience in the activity. The reason for this can be related to the answers found in Question 77 regarding the satisfactory perception of comfort at work and in Question 30 (score 75.50) from Table 4, that addresses the identification of the subject with the task being performed.

Table 2 presents the data from the Psychological Domain where the following factors were evaluated: self-control; self-esteem; team spirit; degree of responsibility; freedom of expression; pride of the work and safety.

Table 1- Distribution of means, standard deviations of the results in the scale 1-5, and results in the scale 0-100 built from the questions of the Physical/Health Domain ( $n=95)$. Bento Gonçalves, 2014.

\begin{tabular}{|c|c|c|c|}
\hline \multirow{2}{*}{ Questions by domain } & \multicolumn{2}{|c|}{ Scale 1-5 } & \multirow{2}{*}{$\begin{array}{l}\text { Scale } \\
0-100\end{array}$} \\
\hline & $\mathbf{M}$ & SD & \\
\hline $\begin{array}{l}1 \text { How much do you care about your eating } \\
\text { habits? }\end{array}$ & 3.12 & 0.82 & 53.00 \\
\hline 6 How much do you worry about your health? & 3.72 & 0.76 & 68.00 \\
\hline $\begin{array}{l}11 \text { How much do you worry about pain or } \\
\text { discomfort at work? }\end{array}$ & 3.20 & 1.01 & 55.00 \\
\hline $\begin{array}{l}16 \text { To what extent do you struggle to look after } \\
\text { your health? }\end{array}$ & 2.79 & 0.74 & 44.75 \\
\hline 21 Do you practice physical exercises regularly? & 2.47 & 1.10 & 36.75 \\
\hline 26 Do you have any trouble sleeping? & 2.20 & 1.18 & 30.00 \\
\hline 31 How would you rate your sleep quality? & 3.57 & 1.04 & 64.25 \\
\hline $\begin{array}{l}36 \text { To what extent does a sleeping problem } \\
\text { affect your work? }\end{array}$ & 2.20 & 1.18 & 30.00 \\
\hline 43 Do you suffer from headaches? & 2.75 & 1.15 & 43.75 \\
\hline 48 Do you suffer from stomachaches? & 2.15 & 1.15 & 28.75 \\
\hline
\end{tabular}




\begin{tabular}{|c|c|c|c|}
\hline $\begin{array}{l}53 \text { To what extent do you need medication to } \\
\text { be able to work? }\end{array}$ & 1.87 & 0.98 & 21.75 \\
\hline $\begin{array}{l}57 \text { Do you suffer from hereditary diseases } \\
\text { (cholesterol, high blood pressure)? }\end{array}$ & 1.55 & 1.02 & 13.75 \\
\hline 61 How tired do you feel at the end of a workday? & 3.87 & 0.89 & 71.75 \\
\hline $\begin{array}{l}65 \text { To what extent do your pains and/or health } \\
\text { keep you from doing what you need to do? }\end{array}$ & 2.13 & 0.87 & 28.25 \\
\hline $\begin{array}{l}69 \text { Are your basic physiological needs properly } \\
\text { being met? }\end{array}$ & 3.67 & 0.83 & 66.75 \\
\hline $\begin{array}{l}73 \text { Do you practice workplace exercises or any } \\
\text { other kind of physical activity in the company? }\end{array}$ & 1.22 & 0.58 & 5.50 \\
\hline $\begin{array}{l}77 \text { To what extent do you feel comfortable in } \\
\text { your working environment? }\end{array}$ & 3.52 & 0.72 & 63.00 \\
\hline
\end{tabular}

Source: Author (2014).

Table 2- Distribution of means, standard deviations of the results in the scale 1-5, and results in the scale 0-100 built from the questions of the Psychological Domain ( $\mathrm{n}=95)$. Bento Gonçalves, 2014.

\begin{tabular}{|c|c|c|c|}
\hline \multirow{2}{*}{ Questions by domain } & \multicolumn{2}{|c|}{ Scale 1-5 } & \multirow{2}{*}{$\begin{array}{l}\text { Scale } \\
0-100\end{array}$} \\
\hline & $\mathbf{M}$ & SD & \\
\hline 2 How would you rate your self-esteem? & 3.44 & 0.71 & 61.00 \\
\hline $\begin{array}{l}7 \text { How much do you feel inhibited by your looks } \\
\text { in the workplace? }\end{array}$ & 1.82 & 0.88 & 20.50 \\
\hline 12 How well can you concentrate on your work? & 3.82 & 0.65 & 70.50 \\
\hline $\begin{array}{l}17 \text { How would does a negative feeling (sadness, } \\
\text { hopelessness) interfere with your work? }\end{array}$ & 2.56 & 0.96 & 39.00 \\
\hline 22 How would you rate your motivation to work? & 3.35 & 0.88 & 58.75 \\
\hline $\begin{array}{l}27 \text { How would you rate the team spirit of your } \\
\text { work colleagues? }\end{array}$ & 3.40 & 0.96 & 60.00 \\
\hline $\begin{array}{l}32 \text { How would you rate your freedom of } \\
\text { expression in your workplace? }\end{array}$ & 3.15 & 0.82 & 53.75 \\
\hline $\begin{array}{l}37 \text { How would you rate your proud for your } \\
\text { profession? }\end{array}$ & 4.03 & 0.86 & 75.75 \\
\hline $\begin{array}{l}44 \text { How would you rate the safety in the work } \\
\text { environment? }\end{array}$ & 3.39 & 0.70 & 59.75 \\
\hline $\begin{array}{l}49 \text { How does the noise in your work environment } \\
\text { bother you? }\end{array}$ & 2.96 & 1.11 & 49.00 \\
\hline
\end{tabular}

Source: Author (2014). 
Question 7 (score 20.50) addresses the appearance and the inhibition felt by the subject and is related with other studies ${ }^{21}$ that associate QLW to the aspects of internal motivation. If the subjects are not happy with the way they look, it is unlikely they will find motivation to perform their activities. The classification as being very unsatisfactory (score 20.50) seems to indicate how this issue has an impact on the quality of life of these workers. This issue is related to those in Table 3, since the lack of workplace exercises and diseases related to the hereditary (arterial hypertension and high cholesterol), as well as headaches, can be reflected on the selfperception of the interviewees and their labor activities.

In Question 17 (score 39.00), regarding the negative feelings interfering with work, similar reports were found by other authors. ${ }^{15}$ According to them, there was a dichotomy in the answers, because while thy stated they enjoyed working, considering it pleasant and gratifying, they evaluated several aspects of the work as negative, mainly feeling nervous with the pressure from superiors, repetition, and monotony. In the present study, a similar dichotomy is presented, since the sample indicates the Question 77 (Table 1) as satisfactory, about the perception of comfort at work, and in Question 27 (Table 2), about the team spirit from the work colleagues (score 60.00). This indicates that the relationships between professionals working in the same sector seem to interfere positively with the perception of the sample, so that they help balancing the negative factors that can generate on the QLW of these professionals. Apparently, the motivation and proud to perform the chosen profession, along with the team spirit seem to be preponderant factors in this domain to maintain the QLW of the subjects of the sample.

In Table 4, the Personal Domain evaluated the aspects related to: self-evaluation; own leisure and family's; housing; geographical changes; prejudice; personal privacy; personal achievement; relationship boss-subordinate; relationship work-family; family culture; respect from the colleagues and superiors; transportation/mobility; personal values and beliefs; family values.

Table 3- Distribution of means, standard deviations of the results in the scale 1-5 and results in the scale 0-100 built from the questions of the Professional Domain ( $n=95)$. Bento Gonçalves, 2014.

\begin{tabular}{|c|c|c|c|}
\hline \multirow{2}{*}{ Questions by domain } & \multicolumn{2}{|c|}{ Scale 1-5 } & \multirow{2}{*}{ Scale $\mathbf{0 - 1 0 0}$} \\
\hline & $M$ & SD & \\
\hline 4 How often do you miss work due to illness? & 1.66 & 0.66 & 16.50 \\
\hline 5 How often do you get ill because of work? & 1.83 & 0.94 & 20.75 \\
\hline $\begin{array}{l}9 \text { How would you rate the access to the medical care } \\
\text { at work? }\end{array}$ & 3.19 & 1.15 & 54.75 \\
\hline 14 How do you evaluate your autonomy in your work? & 3.67 & 0.90 & 66.75 \\
\hline $\begin{array}{l}19 \text { How would you rate the cooperation between the } \\
\text { hierarchical levels in your workplace? }\end{array}$ & 3.14 & 0.83 & 53.05 \\
\hline $\begin{array}{l}20 \text { How would you rate your freedom to create new } \\
\text { things at work? }\end{array}$ & 2.64 & 1.061 & 41.00 \\
\hline $\begin{array}{l}25 \text { How often are you forced to change your house } \\
\text { routine because of work? }\end{array}$ & 2.80 & 1.03 & 45.00 \\
\hline $\begin{array}{l}30 \text { To what extent do you identify yourself with the task } \\
\text { you perform? }\end{array}$ & 4.02 & 0.81 & 75.50 \\
\hline
\end{tabular}




\begin{tabular}{|c|c|c|c|}
\hline $\begin{array}{l}34 \text { How often do you think about radically changing } \\
\text { your job? }\end{array}$ & 2.68 & 1.21 & 42.00 \\
\hline $\begin{array}{l}35 \text { To what extent are you proud of the organization } \\
\text { where you work? }\end{array}$ & 3.43 & 0.73 & 60.75 \\
\hline $\begin{array}{l}46 \text { To what extent are you satisfied with the level of } \\
\text { participation in the decisions of the company? }\end{array}$ & 2.43 & 0.87 & 35.75 \\
\hline $\begin{array}{l}47 \text { How do you evaluate the sharing of productivity } \\
\text { gains in your company? }\end{array}$ & 2.11 & 0.93 & 27.75 \\
\hline 52 How do you evaluate your salary for your work? & 2.36 & 0.84 & 34.00 \\
\hline $\begin{array}{l}55 \text { How often do you need other sources of income to } \\
\text { support you? }\end{array}$ & 3.32 & 1.24 & 58.00 \\
\hline $\begin{array}{l}60 \text { Are you satisfied with the feedback given by the } \\
\text { organization about your work? }\end{array}$ & 2.83 & 0.88 & 45.75 \\
\hline $\begin{array}{l}64 \text { To what extent are you satisfied with your ability to } \\
\text { learn? }\end{array}$ & 4.04 & 0.63 & 76.00 \\
\hline $\begin{array}{l}67 \text { To what extent are you satisfied with the variety of } \\
\text { tasks that you perform? }\end{array}$ & 3.34 & 0.87 & 58.50 \\
\hline 68 Is your private life preserved in the work environment? & 3.75 & 0.94 & 68.75 \\
\hline 71 How stable do you feel about your job? & 3.53 & 0.78 & 63.25 \\
\hline $\begin{array}{l}72 \text { How would you rate the team spirit in your } \\
\text { workplace? }\end{array}$ & 2.99 & 0.96 & 49.75 \\
\hline $\begin{array}{l}78 \text { How much are you satisfied with your quality of life } \\
\text { at work? }\end{array}$ & 2.97 & 0.88 & 49.25 \\
\hline
\end{tabular}

Source: Author (2014).

Table 4- Distribution of means, standard deviations of the results in the scale 1-5, and results in the scale 0-100 built from the questions of the Personal Domain ( $n=95)$. Bento Gonçalves, 2014.

\begin{tabular}{|c|c|c|c|}
\hline \multirow[t]{2}{*}{ Questions by domain } & \multicolumn{2}{|c|}{ Scale 1-5 } & \multirow[t]{2}{*}{ Scale $0-100$} \\
\hline & M & SD & \\
\hline $\begin{array}{l}3 \text { How would you rate your ability of self-evaluation in } \\
\text { your work? }\end{array}$ & 3.78 & 0.62 & 69.50 \\
\hline $\begin{array}{l}8 \text { To what extent do you evaluate the quality of your } \\
\text { leisure activities and your family's? }\end{array}$ & 2.81 & 0.82 & 45.25 \\
\hline 13 To what extent is your housing adequate? & 4.35 & 0.65 & 83.75 \\
\hline $\begin{array}{l}23 \text { Have you ever suffered any prejudice in your } \\
\text { workplace? }\end{array}$ & 1.54 & 0.83 & 13.5 \\
\hline $\begin{array}{l}28 \text { How would you rate your personal privacy in your } \\
\text { work? }\end{array}$ & 3.40 & 0.88 & 60.00 \\
\hline 33 Do you feel fulfilled with your work? & 3.71 & 0.96 & 67.75 \\
\hline
\end{tabular}


38 How would you rate the quality of the relationships

with your superiors and/or subordinate?

45 To what extent does your family evaluate your work?

50 Do you have difficulties in your family because of your work?

54 Do you suffer difficulties at work because of your family culture?

70 To what extent do you have the proper transportation means to go to work?

74 How much are you satisfied with your ability to help others in your work?
3.54

0.76

63.50

3.78

0.97

69.50

2.11

1.07

27.75

1.37

0.75

09.25

3.44

1.23

61.00

3.98

0.66

Source: Author (2014).

Results observed in Question 50 addressing the difficulties perceived by the subjects with the family due to their work, classified by the participants as unsatisfactory, are similar to other studies. ${ }^{22,8,10}$ They noticed conflicts related to the professional and personal demands, because of the double work shift, leading to a loss of the participation in cultural, social, school, and family activities.

Questions 23 and 54, rated as being very unsatisfactory, can be related to conclusions from other studies, ${ }^{23-25}$ given that the subjects may not be able to buy things with their salary, and this would make them feel at disadvantage compared to the other members of the multidisciplinary staff.

The Professional Domain, presented in Table 3, evaluates aspects, such as absenteeism; medical care; autonomy; bureaucracy; working hour; cooperation between hierarchical levels; credibility of the superiors; creativity; education; internal and external equity; schedule stability; ability and availability of employees; identification with the task; image of the company (pride); accidents at work; information on total processes of the work; goals and objectives; level of challenge; participation in the decisions; sharing of productivity gains; career plan and learning; salary; feedback/ having their work recognized; training; variety of the task and personal life preserved.

Question 4 (score 16.50) addresses the frequency a subject is absent from work, with this being considered as unsatisfactory by the sample. Their results are similar to those of other studies ${ }^{26,27}$ that associated absenteeism with factors as disease and work overload.

Question 5 deals with the relation made by the subject between emergency of illnesses and execution of work (score 20.75), with this being considered unsatisfactory by the sample. The workload and the relation with illness were the topic of studies by several authors. Ramos et al. ${ }^{28}$ pointed the presence of psychophysical repercussions, such as arterial hypertension, while Magalhães et al. ${ }^{29}$ indicated the presence of tow diseases: both high blood pressure $(72.90 \%)$ and high cholesterol $(27.80 \%)$. The presence of headaches in nursing professionals was also mentioned by Oliveira and Pelógia ${ }^{17}$ and Santos, ${ }^{18}$ who relate them with excessive work schedule and routine to which the professionals were subjected.

Question 20, rated as unsatisfactory by the sample, addresses the freedom to create new thing at work. This was the study topic of seminal authors, such as Hackman and Oldham, ${ }^{21}$ who associated QLW to aspects of internal motivation, satisfaction with the position, and enrichment of the position, which includes the perception of the meaning of the task (variety of abilities, identification of the task), meaning of the task, autonomy, and task.

Other issues of this domain were considered as unsatisfactory: 46 (score 35.75), addressing the satisfaction by participating in the decisions of the companies; 47 (score 27.75), addressing with sharing the productivity gains; 51 (score 42.75), addressing building a career and/or salary raises; and 52 (score 34.00), addressing 
the salary obtained by their work. They are related to the results from several studies ${ }^{23-25}$ considering the low wages as an impacting factor on the quality of life of the worker. The scores resulting from Questions 46 and 47 indicate that the subjects of the sample do not see themselves as participants in the decision-making processes nor compensated by the gains they achieve with their work. These considerations are supported by other authors, $^{30}$ who found relations between these factors, indicating the management models as potentially causing loss is QLW.

Question 78 (score 49.25) addressing how satisfied the subject is with the quality of life at work. This neutrality can be connected to the lack of motivation already seen in previous questions and dichotomy presented in

\section{FINAL CONSIDERATIONS}

The Physical/Health, Personal, Professional, and Psychological Domains, as they were predicted by the instrument, allowed for a better comprehension of the perception of nursing professionals of the hospital used as the unit of study. Regardless the lack of 80 professionals in the workplace, what has led nursing professionals to make double shifts, the respondents classified all domains as being satisfactory.

However, there are important issues to be solved by the organization. Factors, such as salary, perception of sharing the gains obtained with productivity, career plan, freedom to create new things, conflicts between personal and professional life, differences between the professionals' and the organizations' personal values, workplace exercises as a tool to improve the subjects' daily wellness and self-perception, besides the preventive care with health, aiming at using a smaller number of medications, deserve special attention by the management, since those can produce the unwanted high rotation.

The sample being investigated presented a satisfactory perception of Quality of Life at Work, as well as a strong positive correlation between all the domains and the QLW. The Personal Domain presented the highest correlation with QLW ( $p=0.866)$, followed by the Psychological
Question 17, where the subjects state that they enjoy their work, but indicated several negative aspects when they are performing it ${ }^{31,21}$.

Besides the questions already discussed, it is interesting to stress that the subjects of the sample feel they are capable to learn (score 76.00) and rate the training (score 60.75) and the access to information (score 60.25) as satisfactory. It must be highlighted the identification the subjects felt with the tasks performed (score 75.50) and their variety (score 58.50), and this is reflected in these subjects' motivation. Such results are important, because they serve as an indicator that the sample subjects are satisfied with the tasks performed and that improvements can be made in training and access to information, which will affect the quality of the work being made.

and Professional Domains (both with $\mathrm{p}=0.819$ ) and by Physical/Health Domain $(p=0.762)$.

Thus, the development of several actions involving factors that are embedded in the four domains tends to enhance the QLW in the institution. Improvement of hierarchical, social, and family relationships; encouraging of physical activities and workplace exercises; self-esteem and freedom of expression; sense of belonging and equity; feedback; and access to information on several work processes can be mentioned as such actions.

Therefore, they are actions that do not necessarily involve financial resources and are directly connected with the capacity to manage people.

As suggestions for future studies, the direct relationship between rotation and loss of quality of life at work can be addressed. Moreover, it would be interesting to apply these questionnaires in similar hospitals, in order to investigate their differences and similarities, by using their strengths as management practices.

The limiting factors of the present study are: it was applied in only one hospital unit, the number of respondents, and the size of the questionnaire, which requires a degree of attention and time, which may discourage potential respondents, though it has been previously validated. 


\section{REFERENCES}

1. Manenti SA, Ciampone MHT, Mira VL, Minami LF, Soares JMS. O processo de construção do perfil de competências gerenciais para enfermeiros coordenadores de área hospitalar. Rev Esc Enferm USP. 2012;46(3):727-33.

2. Ribeiro RP, Martins JT, Marziale MHP, Robazzi MLC. C. O adoecer pelo trabalho na enfermagem: uma revisão integrativa. Rev Esc Enferm USP. 2012;46(2):495-504.

3. Kurogi MS. Qualidade de vida no trabalho e suas diversas abordagens. R C Gerenc. 2008;12(16):49-62.

4. Feuerwerker LCM, Cecilio LCO. O hospital e a formação em saúde: desafios atuais. Ciênc saúde coletiva [online]. 2007;12(4):965-71 [cited 2013 May 08]. Available from: http://www.scielo.br/scielo.php?script=sci_arttext\&pid=S1413-81232007000400018

5. Silva GM, Seiffert OMLB. Educação continuada em enfermagem: uma proposta metodológica. Rev Bras Enferm. 2009;62(3):362-6. 6. Federação das Santas Casas e Hospitais Beneficentes, Religiosos e Filantrópicos do Rio Grande do Sul [Internet]. Diretoria. Porto Alegre: 2013 [cited 2013 May 08]. Available from: http://federacaors.org.br/contents/detail/3

7. Stumm EM, Oliveski CC, Costa CFL, Kirchner RM, Silva LAA. Estressores e coping vivenciados por enfermeiros em um serviço de atendimento pré-hospitalar. Cogitare Enferm. 2008;13(1):33-43.

8. Panizzon C, Luz AM, Fensterseifer LM. Estresse da equipe de enfermagem de emergência clínica. Rev Gaúcha Enferm. 2008;29(3):3919.

9. Silveira MM, Stumm EM, Kirchner RM. Estressores e coping: enfermeiros de uma unidade de emergência hospitalar. Rev Eletr Enf. 2009;11(4):894-903.

10. Dalri RC, Robazzi ML, Silva LA. Occupational hazards and changes health among Brazilian professionals nursing from urgency and emergency units. Cienc Enferm. 2010;16(2):69-81.

11. Schmidt DRC, Dantas RAS, Marziale MHP. Qualidade de vida no trabalho: avaliação da produção científica na enfermagem brasileira. Acta Paul Enferm. 2008;21(2):330-7.

12. Reis Júnior DR. Qualidade de vida no trabalho: construção e validação do questionário QWLQ-78 [dissertation]. Ponta Grossa, PR: Universidade Tecnológica Federal do Paraná/Programa de Pós-Graduação em Engenharia de Produção; 2008.

13. Siviero IMPS. Saúde mental e qualidade de vida de infartados [thesis]. Ribeirão Preto, SP: Escola de Enfermagem de Ribeirão Preto, Universidade de São Paulo; 2003

14. Dancey C, Reidy J. Estatística sem matemática para psicologia: Usando SPSS para Windows. Porto Alegre: Artmed; 2006.

15. Renner JS, Taschetto DVR, Baptista GL, Basso CR. Qualidade de vida e satisfação no trabalho: percepção dos técnicos de enfermagem que atuam em ambiente hospitalar. REME. 2014;18(2):440-6.

16. Vieira TG, Beck CLC, Dissen, CM, Camponogara S, Gobatto M, Coelho APF. Adoecimento e uso de medicamentos psicoativos entre trabalhadores de enfermagem em unidades de terapia intensiva. REUFSM. 2013;3(2):205-14.

17. Oliveira ALM, Pelógia NCC. Cefaleia como principal causa de automedicação entre os profissionais da saúde não prescritores. Rev Dor. 2011;12(2):99-103.

18. Santos SRB. Sentidos da Automedicação para enfermeiras de hospital público do município de Niterói [dissertation]. Rio de Janeiro: Escola Nacional de Saúde Pública Sergio Arouca; 2011.

19. Ferracini GN, Valente FM. Presença de sintomas musculoesqueléticos e efeitos da ginástica laboral em funcionários do setor administrativo de um hospital público. Rev Dor. 2010;11(3):233-6.

20. Manosso M, Lanferdini FJ, Dal'agnol MJ, Roncada C, Dias CP. Comparação dos níveis de estresse e estilo de vida entre praticantes e não praticantes de ginástica laboral. RBCM. 2014;22(2):65-71.

21. Hackman JR, Oldham GR. The job diagnostic survey: an instrument for the diagnosis of jobs and the evaluation of job redesign projects. Technical report, Department of Administrative Sciences of Yale University, n. 4, May 1974.

22. Paschoa S, Zanei SSU, Whitaker JY. Qualidade de Vida dos Trabalhadores de Enfermagem em unidades de Terapia Intensiva. Acta Paul Enferm. 2007;20(3):305-10.

23. Passos JB, Silva EL, Carvalho MMCC. Estresse no centro cirúrgico: uma realidade dos profissionais de enfermagem. Rev Pesq Saúde. 2010;11(2):35-8.

24. Ramos EL. A qualidade de vida no trabalho: dimensões e repercussões na saúde do trabalhador de enfermagem de terapia intensiva [dissertation]. Rio de Janeiro (RJ): Universidade do Estado do Rio de Janeiro. Faculdade de Enfermagem; 2009.

25. Westley WA. Problems and solutions in the quality of working life. Humans Relations. 1979;32(2):111-23.

26. Ferreira MC, Alves L, Tostes N. Gestão de Qualidade de Vida no Trabalho (QVT) no Serviço Público Federal: O Descompasso entre Problemas e Práticas Gerenciais. Psic: Teor e Pesq. 2009;25(3):319-27.

27. Mininel VA, Baptista PCP, Felli VEA. Cargas psíquicas e processos de desgaste em trabalhadores de enfermagem de hospitais universitários brasileiros. RLAE. 2011;19(2).

28. Ramos EL, Souza NVDO, Pires AS, Gonçalves FGA. A qualidade de vida no trabalho: dimensões e repercussões na vida do trabalhador de enfermagem de terapia intensiva. In: Seminário Nacional de Pesquisa em Enfermagem, v. 16, Campo Grande, MS. Anais.... 2011.

29. Magalhães FE, Mendonça LBA, Rebouças CBA, Lima FET, Custódio IL, Oliveira SC. Fatores de risco para doenças cardiovasculares em profissionais de enfermagem: estratégias de promoção da saúde. Rev Bras Enferm. 2014;67(3):394-400.

30. Azambuja EP, Pires EPP, Vaz MRC, Marziale MH. É possível produzir saúde no trabalho da enfermagem? Texto Contexto Enferm. 2010;19(4):658-66

31. Meneghini F, Paz AA, Lautert L. Fatores Ocupacionais Associados aos Componentes da Síndrome de Burnout em Trabalhadores de Enfermagem. Texto Contexto Enferm. 2011;20(2):225-33.

Recebido em 12 de agosto de 2015. Aprovado em 01 de junho de 2016. 